\title{
Diagnóstico geoambiental da bacia do córrego Tenente em Mariluz, Paraná, Brasil
}

\author{
Marta Luzia de Souza ${ }^{1}$, Nelson Vicente Lovatto Gasparetto ${ }^{1}$ \& Paulo Nakashima ${ }^{1}$
}

\begin{abstract}
Resumo A Prefeitura Municipal de Mariluz solicitou ao Departamento de Geografia da Universidade Estadual de Maringá um diagnóstico geoambiental da bacia do córrego Tenente, visando avaliar seu estágio de degradação, em decorrência dos diferentes usos do solo. Essa bacia está localizada no sudoeste do município, sobre arenitos da Formação Caiuá. Essa litologia, aliada ao predomínio do clima quente e úmido da região, deu origem a uma cobertura pedológica de textura arenosa muito friável que em razão do manejo dos solos originou diversos tipos de feições erosivas. O objetivo do presente trabalho é mostrar os resultados do diagnóstico geoambiental efetuado a partir de trabalhos de campo e de análises laboratoriais na área em questão. Dentre as diversas formas de degradação ambiental, destacaram-se, entre as mais significativas: ausência de vegetação ripária em vários trechos dos cursos d'água, presença de feições erosivas, movimentos de massa e assoreamento dos canais de drenagens. Todas essas informações foram agrupadas em cartas temáticas, escala 1:50.000, no formato digital. Os documentos cartográficos e seus respectivos memoriais produzidos foram as cartas temáticas: de hipsometria, de declividade, de orientação de vertentes, de uso e ocupação do solo (1970, 1980 e 2006) e a morfopedológica.
\end{abstract}

Palavras-chave: degradação ambiental, solos arenosos, cartas temáticas.

\begin{abstract}
Geo-environmental diagnosis of the Tenente stream basin, Mariluz, state of Paraná, Brazil. The municipal authorities of Mariluz (state of Paraná, Brazil) requested the Geography Department of the State University of Maringá (Maringá, state of Paraná) to undertake a geo-environmental diagnosis of the Tenente Stream basin to evaluate degradation caused by different uses of the soil. The above basin, located in the southwestern part of the municipality, lies on the Caiuá Rock Sandstone formation. This lithology, allied to the hot and humid climate of the region, gave rise to a very friable and sandy pedological cover. Incorrect use of the soil led to diverse types of erosional features. Current research shows the results of the geo-environmental diagnosis taken from field work and lab analysis done in the area. The most significant forms of environmental degradation are lack of riparian vegetation in several stretches of the stream, presence of erosional features, material accumulation and silting of drainage channels. All this information was digitalized in thematic charts (scale 1:50,000). The cartographic documents and their respective summaries made up these charts of hypsometry, declivity, slope orientation, use and occupation of the soil (1970, 1980 and 2000) and morphopedology.
\end{abstract}

Keywords: environmental degradation, sandy soils, thematic charts.

INTRODUÇÃo O crescimento populacional de aglomerações urbanas no Brasil tem ocorrido, nos últimos anos, em geral de forma desordenada, desencadeando uma série de problemas ambientais, que se reproduzem de diferentes formas na sociedade. Com a criação do Estatuto da Cidade (Brasil 2001) que se refere a Lei 10.257, onde as aglomerações urbanas com mais de 20.000 habitantes precisam elaborar ou mesmo readequar seus planos diretores.

Para o desenvolvimento desses planos diretores é imprescindível a elaboração de produtos cartográficos, para dar subsídios à tomada de decisões, visando uma ocupação que reduza ao máximo a degradação do meio físico. Esse não é o caso oficial da cidade de Mariluz, localizada na Região Noroeste do Paraná (Fig. 1), uma vez que a mesma apresenta população em torno de 9.800 habitantes (IPARDES 2005). No entanto, o mu- nicípio apresenta sua economia voltada para as atividades agropecuárias, desenvolvidas sobre um substrato rochoso e friável da Formação Caiuá. Essa formação dá origem a materiais de textura arenosa, inconsolidados, muito susceptíveis ao desenvolvimento de feições erosivas e outros processos como movimentos de massa nas vertentes e assoreamento dos cursos d'água.

Em decorrência desses problemas, que começaram a afetar a economia do município, a Prefeitura Municipal de Mariluz solicitou um diagnóstico geoambiental da bacia do córrego Tenente. O estudo teve o intuito de avaliar o estágio da degradação ambiental da bacia, em decorrência dos diferentes usos do solo a partir da década de 1970, em razão de ser uma área passível de expansão urbana e, também, pela mudança drástica de uso do solo, isto é, de cultura permanente para temporária. 


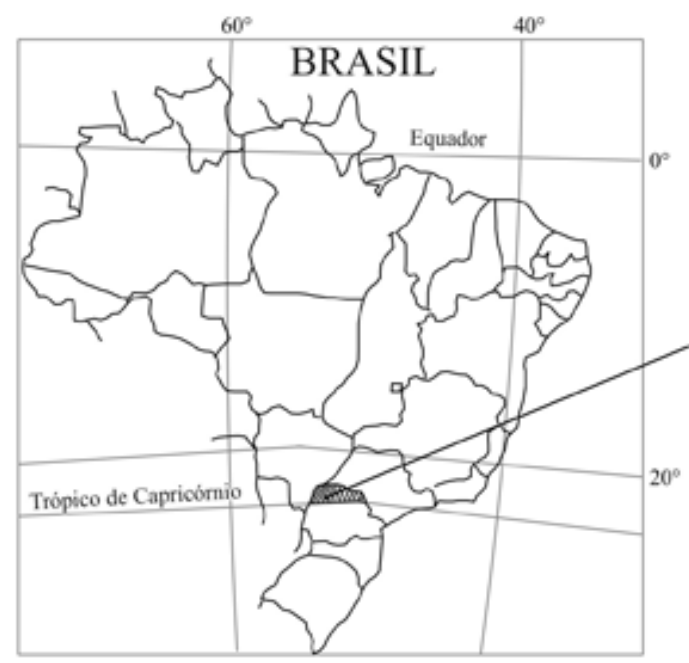

$500 \quad 0 \quad 500 \quad 1000 \mathrm{Km}$

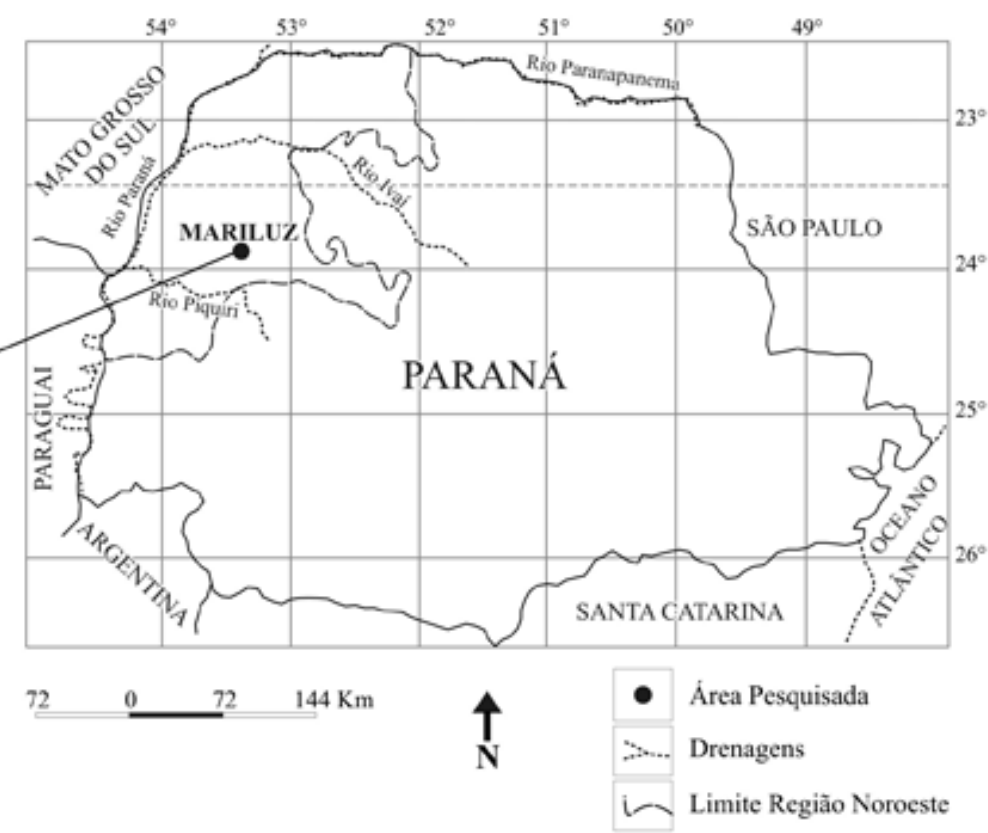

Figura 1 - Localização da área de estudo.

Após a retirada da vegetação original da bacia, implantou-se a cultura do café, que permaneceu até meados da década de 1970. Com o declínio da lavoura cafeeira, foram implantadas novas culturas, como o trigo, o milho e o algodão, além de pequenas áreas de pastagem. Atualmente, a bacia é ocupada preferencialmente por culturas temporárias principalmente de soja e, secundariamente, de milho e cana-de-açúcar.

A proposta de mudança de uso e ocupação dos solos se deve em parte a incentivos governamentais e das cooperativas da região, que têm como objetivo apoiar o avanço da agricultura e da pecuária na região de ocorrência da Formação Caiuá com o projeto denominado "Arenito Nova Fronteira". Pequenos setores da bacia são ainda ocupados pelas pastagens.

Em razão das propriedades físicas e químicas apresentadas pelos solos derivados do arenito, que são friáveis e de baixa fertilidade natural, sua utilização para determinados fins agrícolas pode ser questionada. Com a finalidade de levantar e reunir subsídios à ocupação mais racional da bacia, foram elaboradas várias cartas temáticas, visando diagnosticar a degradação ambiental da área.

MÉTODOS Após a revisão bibliográfica de várias metodologias que envolvem a elaboração de diagnósticos ambientais no Brasil, foram adotados os princípios metodológicos norteadores propostos por Beltrame (1994) e Ross (1991). No levantamento dos atributos, ou parâmetros, foram determinados os principais atributos que subsidiaram o diagnóstico geoambiental da bacia em estudo. Foram eles o substrato rochoso e a cobertura pedológica, aliados aos aspectos geomorfométricos do relevo, que condicionaram, em parte, o uso e a ocupação da área. Os dois últimos atributos deram suporte à elaboração das cartas temáticas. Ressalta-se que os atributos foram escolhidos, a partir do objetivo da pesquisa aliado aos fatores disponibilidade de produtos cartográficos versus escala.

Para a elaboração das cartas temáticas foi necessária a elaboração de uma base cartográfica, realizada a partir da delimitação da bacia na Folha Topográfica Goioerê (IBGE 1991) na escala 1:50.000. Os softwares utilizados para a elaboração das cartas foram os seguintes: AutoCad ${ }^{\circledR}$ (AUTODESK 2000), "SPRING ${ }^{\circledR}$, versão 4, (INPE 2004 ) e "Surfer for Windows ${ }^{\circledR}$, versão 7, (GOLDEN SOFTWARE, 1999). Os produtos cartográficos, hipsometria, declividade, orientação de vertentes, uso e ocupação do solo (1970, 1980 e 2006) e morfopedologia foram obtidos a partir do uso da base cartográfica digital, da interpretação de fotografias aéreas 1:25.000 (IBC 1970 \& ITC 1980), imagens TMLandsat (EMBRAPA 2001) e de saídas de campo com o uso do Global Positionning System (GPS).

A carta hipsométrica é a representação altimétrica do relevo de uma determinada região. As classes de cores utilizadas na representação variam de acordo com as variações altimétricas, escala e conseqüentemente eqüidistâncias das curvas de nível, pois, quanto maior a variação altimétrica, maior é o número de classes (Oliveira 1988).

No caso em estudo, foram adotadas 5 classes hipsométricas, sendo utilizadas as seguintes colorações para as respectivas cotas com eqüidistância de $20 \mathrm{~m}$ : verde-claro (340-360), amarelo-claro (360-380), amarelo-escuro (380-400), laranja (400-420) e vermelho (420-440).

A carta foi elaborada a partir da base cartográfica digital (CAD no formato $* \mathrm{dxf}$ ), exportada para o interpolador Dxf2xyz e produzida no "Surfer for Window 
®, versão 7, (GOLDEN SOFTWARE, 1999).

A carta de declividade foi elaborada segundo os critérios propostos por De Biasi (1990), que descreve a finalidade dessas cartas para os mais variados usos e tipos de ocupação do espaço, seja ele urbano ou rural.

Na elaboração da carta do presente trabalho as classes de declividade foram determinadas segundo os critérios do autor, em razão dos possíveis fins ocupacionais mistos da bacia. As classes principais foram definidas da seguinte maneira: $(<5 \%)$ limite urbano-industrial; (5-12\%) intervalo que delimita o limite máximo de mecanização na agricultura; (12-30\%) intervalo que delimita o limite máximo para a urbanização sem restrições (Lei Lehmann 6766/79 in De Biasi 1990) e (30-47\%) o Código Florestal fixa o limite de $25^{\circ}$ (47\%) como limite máximo de corte raso.

As principais etapas realizadas após a determinação preliminar das classes de declividade foram a edição e correção dos vetores em ambiente CAD a partir da base cartográfica com atribuição da elevação, construção do modelo de terreno a partir de uma rede irregular triangular (TIN), conversão do modelo TIN para o GRID e confirmação das classes de declividade por meio do modelo GRID com o emprego do "software SPRING ${ }^{\circledR}$, versão 4, (INPE 2004).

A carta de orientação de vertentes pode ser elaborada para uma determinada bacia hidrográfica, com o intuito de subsidiar o uso e a ocupação, tanto no meio rural quanto no urbano, em razão da disposição de suas vertentes. Na análise do fluxo de energia solar dentro da bacia hidrográfica, é possível identificar áreas que recebem maior ou menor luminosidade e quantidade de calor. A distribuição diferenciada da energia solar influencia diretamente na formação de microclimas e no desenvolvimento diferenciado da vegetação. Embora a aplicação da carta de orientação de vertentes tenha sua importância diretamente proporcional ao incremento da latitude, nas áreas de latitude medianamente baixas ela pode auxiliar, na melhor ocupação do solo. Em razão disso, e desde que a carta seja bem utilizada, ela se constitui em boa ferramenta para o planejamento mais racional da bacia.

Com o advento das técnicas digitais, a elaboração da carta de orientação de vertentes tornou-se mais precisa e rápida (Castro \& Viadana 2002), mas ressaltase a necessidade do acompanhamento minucioso dos princípios básicos preconizados nas técnicas analógicas por Gol' Tsberg (1969) e De Biasi et al. (1977). A carta foi elaborada a partir da base cartográfica digital (CAD no formato *dxf), exportada para o interpolador Dxf2xyz e produzida no "Surfer for Window ${ }^{\circledR}$, versão 7, (GOLDEN SOFTWARE, 1999).

As cartas de uso do solo da bacia foram elaboradas para três períodos distintos, 1970, 1980 e 2006, após o desenvolvimento do histórico da ocupação do município, realizado por pesquisas bibliográficas e entrevistas, em 10 propriedades, com os proprietários e/ ou arrendatários. Esses períodos foram escolhidos por serem representativos nas mudanças socioeconômicas ocorridas na região, conjugadas à disponibilidade de sensores remotos com a escala compatível com os objetivos da pesquisa. Para a elaboração dessas cartas foram utilizadas bases cartográficas digitais aliadas às informações da interpretação de fotografias aéreas (IBC 1970 \& ITC 1980). Para 2006 foi feita uma atualização sobre a imagem TM do Landsat disponível pela EMBRAPA (2001) e campo.

A carta morfopedológica é um tipo de documento cartográfico que auxilia diretamente na caracterização do relevo e apresenta as áreas críticas quanto à instabilidade, definindo a dinâmica atual da paisagem e registrando os principais eventos. A morfopedologia identifica os produtos de inter-relação entre o substrato geológico, relevo e solos, que constituem unidades têmporo-espaciais e intrínsecas do meio físico reconhecíveis em médias e grandes escalas, segundo Ribeiro \& Salomão (2003).

Para Correia \& Fontes (2005), a aplicação do conhecimento geomorfológico, que engloba especificadamente as feições topográficas e os processos morfogenéticos atuantes numa determinada área, é relevante para as categorias de uso do solo nas atividades agrícolas, lazer e turismo, diagnóstico das condições ambientais, entre outros empregos. Finalmente, essa carta auxilia na identificação dos estágios de degradação ambiental, pois apresenta as áreas onde os terrenos são mais ou menos susceptíveis à ocorrência de feições erosivas, movimentos de massa, entre outros, pois o mapa morfopedológico facilita a avaliação do meio físico na seleção das áreas num plano de ordenação do espaço.

Os parâmetros geomorfométricos considerados na análise do relevo foram a hipsometria, a declividade e a orientação de vertentes. O produto final da carta foi o obtido a partir do cruzamento das cartas de declividade, hipsométrica, de orientação de vertentes, de uso do solo de 2006, considerando-se os levantamentos de 1970 e 1980 e levantamento dos indicadores geoambientais de degradação. Para a elaboração da carta foi utilizada a base cartográfica digital, aliadas às informações da interpretação de fotografias aéreas (ITC 1980) e a imagem TM do Landsat (EMBRAPA 2001) e atualizações em campo.

As terminologias adotadas para as feições erosivas e movimentos de massa presentes na área foram as dos seguintes autores: laminar (Bennett 1939); linear: sulcos (Fournier 1960); piping (Carson \& Kirkby 1975); erosão marginal: (Morgan 1995) e movimentos de massa (Varnes 1978).

ÁREA DE ESTUDO A bacia do córrego Tenente, pertencente à bacia do rio Piquiri, situa-se entre as latitudes $24^{\circ} 04^{\prime} 56^{\prime \prime}$ e $24^{\circ} 00^{\prime} 28^{\prime \prime} \mathrm{S}$ e entre as longitudes $53^{\circ} 14^{\prime} 24^{\prime \prime}$ e $53^{\circ} 10^{\prime} 42^{\prime \prime} \mathrm{W}$, com uma área total de $29,54 \mathrm{~km}^{2}$ e está localizada na porção sudoeste do município de Mariluz com altitudes que variam de 340 a $440 \mathrm{~m}$.

O clima da área foi classificado regionalmente por Maack (1981), segundo o modelo classificatório de Köppen (1948), que o incluiu na zona climática de transição Tropical-Subtropical, com clima do tipo Cfa, ou seja, mesotérmico, pluvial quente-úmido e por ve- 
zes temperado, com inverno seco de julho a setembro. As análises pluviométricas de uma série histórica da região (1974-1999) indicaram que os maiores índices de precipitação concentraram-se nos meses de outubro $(175,1 \mathrm{~mm})$, dezembro $(187,7 \mathrm{~mm})$ e janeiro $(180,2 \mathrm{~mm})$. E o período mais seco ocorreu nos meses de julho $(65,7 \mathrm{~mm})$ e agosto $(73,1 \mathrm{~mm})$, segundo Souza (2001).

A região Noroeste do Paraná, na qual se encontra a bacia em estudo, está inserida na grande unidade geomorfológica conhecida como Terceiro Planalto Paranaense (Maack 1981). A área pesquisada caracteriza-se pela ocorrência de relevo suave ondulado a plano, apresentando colinas amplas de pequena amplitude com perfil retilíneo e convexo contínuo e topos extensos aplainados. As rampas são longas e pouco declivosas, apresentando apenas pequenos trechos próximos aos canais de drenagem com declividades mais acentuadas.

Geologicamente, a área em estudo está inserida na região Centro-Norte da bacia sedimentar do Paraná, e a unidade litoestratigráfica aflorante é representada pela Formação Caiuá (Grupo Bauru) de idade Cretácea inferior.

A cobertura pedológica regional é caracterizada por perfis de solos arenosos desenvolvidos sobre os interflúvios longos e aplainados e nas vertentes de baixa declividade. A cobertura vegetal original da região Noroeste do estado do Paraná foi reduzida devido à expansão da lavoura cafeeira, a partir de 1930. A floresta primária Estacional Semidecidual, que nessa época predominava, está reduzida atualmente a pequenas manchas de florestas. Essas áreas desmatadas deram lugar a outras classificações de vegetação do ponto de vista fisionômico, que são os campos secundários, decorrentes da remoção da vegetação natural anterior. Geralmente esses campos são infestados de ervas invasoras, dando a aparência de campos sujos. As áreas antropizadas com pastagens também são encontradas, compostas basicamente por gramíneas, ciperáceas e algumas ervas e arbustos. Na bacia em questão, grande parte da área foi desmatada, dando lugar a gramíneas (pastagens) e principalmente às culturas de soja e cana-de-açúcar, mas ainda há vestígios de uma vegetação florestal remanescente e por vezes regenerada, concentrada em pequenas áreas no médio curso do córrego Tenente. Verificam-se também fragmentos isolados de áreas antropizadas com pastagens e, ao longo dos cursos d'água ocorrências fragmentadas de uma vegetação ripária degradada.

DIAGNÓSTICO GEOAMBIENTAL O diagnóstico geoambiental da bacia em estudo foi elaborado a partir dos principais atributos do meio físico, substrato rochoso, cobertura pedológica e aspectos geomorfométricos, com o intuito de levantar o histórico da ocupação da área ocorrida com maior intensidade a partir da década de 1970. As análises referentes aos atributos identificados e aos documentos cartográficos elaborados, cartas temáticas, serão descritos e ilustrados na seqüência.

Substrato rochoso $\mathrm{O}$ substrato rochoso da área, composto por arenito é denominado de Formação
Caiuá (Soares et al. 1980). A formação é constituída predominantemente de arenitos de textura média, fina a muito fina, com grãos arredondados a bem arredondados e grau de seleção variando de pobre a muito bem selecionado, com pequenos teores de matriz lamítica na forma de níveis ou lentes.

O substrato apresenta cores que variam do vermelho-arroxeado a vermelho-escuro, porém quando alterado e saturado em água apresenta cor variegada. Nos sopés das vertentes que permanecem saturados por um determinado período do ano pode ocorrer a mobilização do ferro presente nos minerais do arenito, ocasionando o desenvolvimento de níveis com teores de ferro elevados que conferem à rocha alto grau de resistência. $\mathrm{O}$ cimento carbonático está distribuído em todo o pacote, porém sendo mais freqüente na porção basal. A matriz dificilmente ultrapassa $10 \%$ da rocha, a não ser em casos esporádicos, quando ocorre a presença de pequenos nódulos calcários na matriz, que podem atingir $40 \%$ do total da rocha (Suguio 1980, Riccomini et al. 1981). Associadas com o hidróxido de ferro e o cimento carbonático ocorrem, também, porções com silicificação de origem química desenvolvida a partir do intercrescimento secundário de grãos de quartzo, os quais, quando presentes em abundância, conferem elevado grau de resistência à rocha (Fernandes 1992, Gasparetto 1999, Gasparetto \& Carvalho 2001). As estruturas encontradas na Formação Caiuá são bancos individualizados de dimensões variadas, que geralmente exibem estratificação cruzada suborizontal, constituídos de arenitos finos a médios, com bom grau de seleção. Enquanto isso nos bancos com estrutura maciça ocorrem arenitos finos mal selecionados, geralmente com várias modas associadas (Soares et al. 1980, Riccomini et al. 1981, Fernandes 1992).

As rochas dessa formação apresentam comportamento de rochas brandas (Tab. 1). Em razão dos vários graus de alteração presentes no substrato rochoso, pode ser empregada uma escala de graus de alteração como a elaborada pelo Geological Society Engineering Group Working Party Report (1990).

$\mathrm{Na}$ área de estudo o substrato rochoso apresenta-se predominantemente alterado, ou seja, foi classificado com os seguintes graus de alteração: levemente (II), moderadamente (III), intensamente (IV), completamente (V) e o solo residual (VI). Cabe salientar que essa classificação utiliza os graus de alteração da rocha como uma referência básica de campo, necessitando modificações de acordo com a área estudada, principalmente em regiões tropicais.

A coerência dos materiais rochosos pode ser avaliada a partir de testes realizados em campo, onde se estima a resistência ao impacto e ao risco. A tabela 2 apresenta os quatro graus de coerência que podem ser adotados, assim como as características dos mesmos, segundo Maranesi \& Campos (1987).

Em geral, o comportamento do substrato rochoso da área quanto ao grau de coerência mostra-se de medianamente coerente $\left(\mathrm{C}_{2}\right)$ a incoerente $\left(\mathrm{C}_{4}\right)$. No entanto, nos locais onde o arenito encontra-se silicifi- 
Tabela 1 - Escala de graus de alteração adotada do Geological Society Engineering Group Working Party Report (1990).

\begin{tabular}{|c|c|c|}
\hline $\begin{array}{l}\text { Descrição da } \\
\text { alteração }\end{array}$ & $\begin{array}{l}\text { Características do maciço } \\
\text { rochoso }\end{array}$ & $\begin{array}{l}\text { Graus de } \\
\text { alteração }\end{array}$ \\
\hline Solo residual & $\begin{array}{l}\text { Todo o material rochoso foi } \\
\text { decomposto para solo. Todas } \\
\text { as texturas e estruturas foram } \\
\text { destruídas, sem transporte de } \\
\text { solo }\end{array}$ & VI \\
\hline $\begin{array}{l}\text { Rocha } \\
\text { completamente } \\
\text { alterada }\end{array}$ & $\begin{array}{l}\text { Todo o material rochoso está } \\
\text { sendo decomposto para solo. } \\
\text { As texturas e estruturas estão } \\
\text { em grande parte preservadas }\end{array}$ & $\mathrm{V}$ \\
\hline $\begin{array}{l}\text { Rocha } \\
\text { intensamente } \\
\text { alterada }\end{array}$ & $\begin{array}{l}\text { Mais da metade do material } \\
\text { rochoso está sendo decomposto } \\
\text { para solo. Fragmentos de rocha } \\
\text { fresca ou descolorida podem } \\
\text { estar presentes, como uma } \\
\text { estrutura descontínua }\end{array}$ & IV \\
\hline $\begin{array}{l}\text { Rocha } \\
\text { moderadamente } \\
\text { alterada }\end{array}$ & $\begin{array}{l}\text { Pouco menos da metade } \\
\text { do material rochoso está } \\
\text { decomposto para solo. } \\
\text { Fragmentos de rocha fresca } \\
\text { ou descolorida podem estar } \\
\text { presentes, como uma estrutura } \\
\text { contínua }\end{array}$ & III \\
\hline $\begin{array}{l}\text { Rocha } \\
\text { levemente } \\
\text { alterada }\end{array}$ & $\begin{array}{l}\text { Intemperismo apenas ao } \\
\text { longo das descontinuidades e } \\
\text { somente um leve intemperismo } \\
\text { no material rochoso }\end{array}$ & II \\
\hline Rocha sã & $\begin{array}{l}\text { Não são visíveis sinais de } \\
\text { alteração no material rochoso, } \\
\text { intemperismo às superfícies } \\
\text { das maiores descontinuidades }\end{array}$ & I \\
\hline
\end{tabular}

cado, ele mostra-se coerente $\left(\mathrm{C}_{1}\right)$. Segundo Fernandes (1992), a coerência original da rocha é dada pela cimentação predominantemente ferruginosa.

A lixiviação posterior do cimento carbonático pode então reduzir a coesão em setores do maciço rochoso, criando zonas de menor coerência. $\mathrm{O}$ grau de fraturamento do substrato rochoso da área mostra-se variável desde ocasionalmente fraturado (até uma fratura por metro) a extremamente fraturado (com mais de vinte fraturas por metro) segundo o método proposto por Chiossi (1975), onde o número de fraturas é calculado por metro linear, medindo-se a distância perpendicular ao plano de fraturas.

Cobertura pedológica Na região Noroeste do estado do Paraná as chuvas ocorrem em todos os meses do ano, porém alcançando os maiores índices pluviométricos no verão. Dados do IAPAR (2003) mostram que no município de Mariluz a média anual de precipitação é de $1.700 \mathrm{~mm}$. As temperaturas podem cair abai-
Tabela 2 - Graus de coerência para descrição geotécnica em campo (Maranesi \& Campos 1987).

\begin{tabular}{l|l|l}
\hline $\begin{array}{l}\text { Graus de } \\
\text { coerência }\end{array}$ & Símbolo & Características \\
\hline Coerente & $\mathrm{C}_{1}$ & $\begin{array}{l}\text { Quebra-se com dificuldade ao golpe } \\
\text { do martelo, produzindo-se poucos } \\
\text { fragmentos de bordas cortantes. } \\
\text { Superfícies dificilmente riscável } \\
\text { com aço }\end{array}$ \\
\hline $\begin{array}{l}\text { Mediana- } \\
\text { coerente }\end{array}$ & $\mathrm{C}_{2}$ & $\begin{array}{l}\text { Quebra-se facilmente ao golpe } \\
\text { do martelo, produzindo vários } \\
\text { fragmentos quebradiços por pressão } \\
\text { dos dedos. Superfície riscável com } \\
\text { aço, deixando sulcos leves }\end{array}$ \\
\hline $\begin{array}{l}\text { Pouco } \\
\text { coerente }\end{array}$ & $\mathrm{C}_{3}$ & $\begin{array}{l}\text { Quebra-se com muita facilidade } \\
\text { ao golpe do martelo (esfarela), } \\
\text { produzindo muitos fragmentos que } \\
\text { podem ser partidos manualmente. } \\
\text { Superfície riscável com aço, } \\
\text { deixando sulcos profundos }\end{array}$ \\
\hline
\end{tabular}

xo de $0^{\circ} \mathrm{C}$ nos meses de inverno e ultrapassar os $40^{\circ} \mathrm{C}$ no verão. As condições climáticas favoráveis, quente e úmida, aliadas à rocha sotoposta, deram origem a uma cobertura de solos que apresenta textura arenosa e que é muito susceptível aos processos erosivos. Gasparetto (1999), Nakashima (2000) e Gasparetto et al. (2001), ao estudarem a cobertura pedológica de textura arenosa que recobre a Formação Caiuá, verificaram que existe íntima relação entre a morfologia e a dinâmica dessa cobertura. Nos topos e altas vertentes predominam Latossolos vermelhos, e nos setores de média vertente ocorrem os Argissolos vermelho-amarelos, que transicionam, no sopé, para a associação Gleissolo pouco húmico e Neossolo Quartzarênico (Fig. 2).

Cartas temáticas Os produtos cartográficos elaborados para subsidiar o diagnóstico ambiental da bacia do córrego Tenente foram os seguintes: as cartas temáticas geomorfométricas (hipsométrica, de declividade e de orientação de vertentes), de uso e ocupação do solo $(1970,1980$ e 2006) e a morfopedológica.

GEOMORFOMETRIA DA BACIA O relevo da bacia foi levantado e analisado principalmente sob os aspectos geomorfométricos relacionados à hipsometria, à declividade e à orientação de vertentes.

Hipsometria $\mathrm{Na}$ análise hipsométrica da área da bacia em estudo foram adotadas 5 classes definidas a partir dos critérios explicitados na metodologia e mostrados na figura 3. A classe mais baixa (340-360m) engloba as áreas baixas ou os sopés das vertentes e o principal curso d'água, o córrego Tenente. As classes de altitudes medianas $(360-380 \mathrm{~m})$ e $(380-400 \mathrm{~m})$ encerram as mé- 
dias vertentes e as classes hipsométricas mais elevadas $(400-420 \mathrm{~m})$ e (420-440m) encerram as altas vertentes e os topos aplainados.

Declividade A clinografia da bacia em questão apontou a existência de cinco classes de declividade, a partir dos principais critérios explicitados na metodologia. As classes determinadas encontram-se espacialmente delimitadas na figura 4 , onde foram quantificadas suas distribuições (Tab. 3).

$\mathrm{O}$ primeiro fato a se observar quanto à aplicabilidade das classes de declividade é a existência de três compartimentos no relevo (topo, média e baixa vertente) com diferentes comportamentos clinográficos. Do ponto de vista estritamente da declividade, a área abrangida pela bacia encontra-se em um ambiente predominantemente de baixa a média energia em relação ao escoamento superficial, o que pode significar um baixo potencial de remanejamento dos materiais inconsolidados das vertentes até os fundos de vale. De maneira geral, a área de encontro dos afluentes apresenta as maiores classes de declividade, apresentando uma susceptibilidade mais acentuada à ocorrência de feições erosivas. As áreas com inclinações maiores que $20 \%$ são pouco expressivas.

Orientação de vertentes A carta de orientação de vertentes elaborada foi analisada segundo a disposição do principal curso d'água, o córrego Tenente (Fig. 5). No baixo curso do córrego, na margem esquerda ocorre uma predominância de vertentes direcionadas para E,

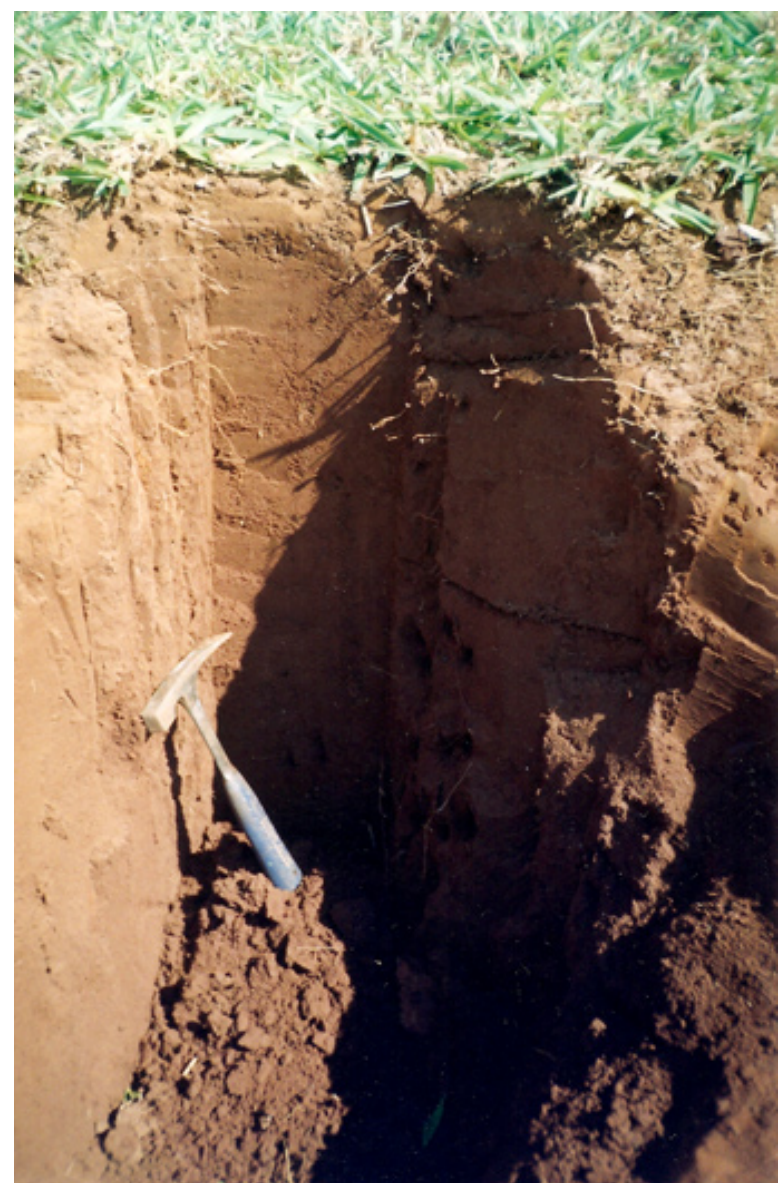

Figura 2 - Perfil do Neossolo Quartzarênico no sopé da vertente.

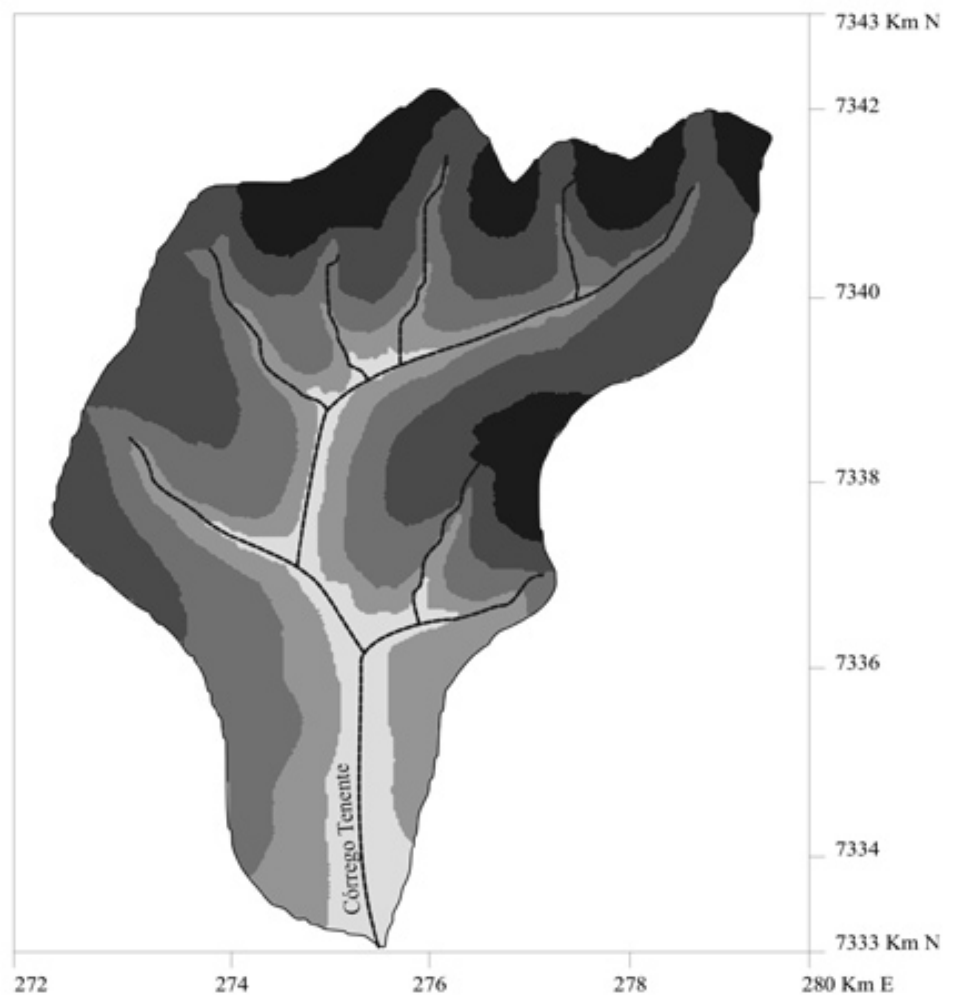

Classes hipsométricas
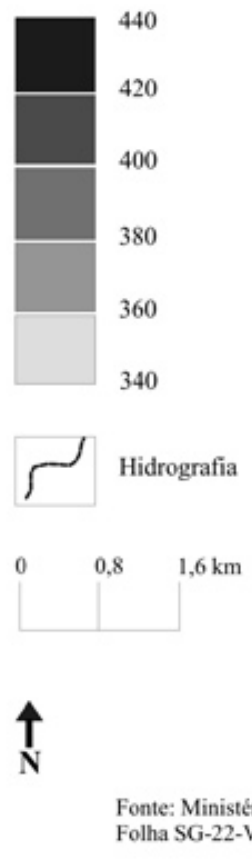

Fonte: Ministério do Exército, escala 1:50.000. Folha SG-22-V-A-II-2 MI-2801/2 Goioerê (1991)

Figura 3 - Carta hipsométrica da bacia do córrego Tenente/Mariluz/PR. 


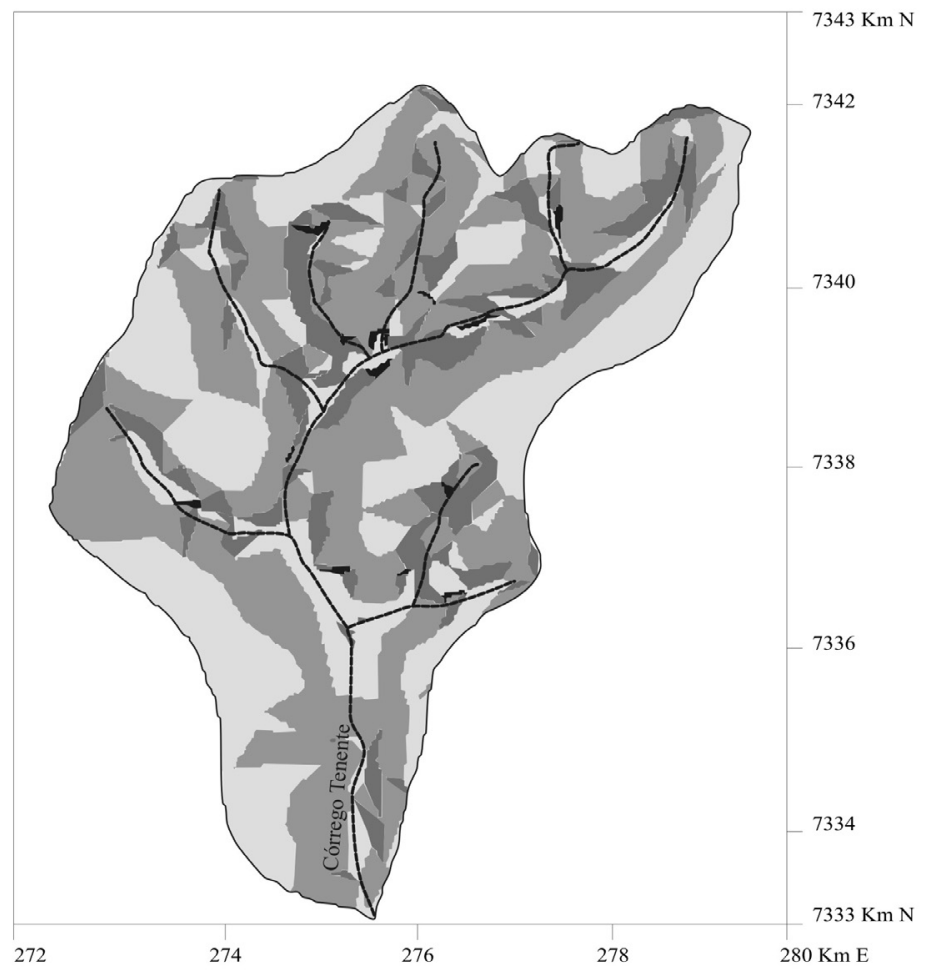

Classes de declividade $(\%)$
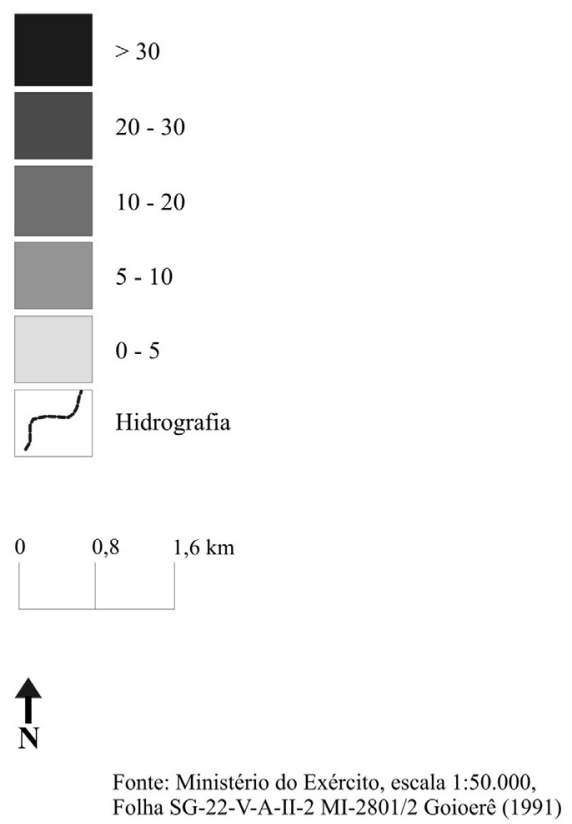

Figura 4 - Carta de declividade da bacia do córrego Tenente/Mariluz/PR.

e na margem direita do curso hídrico as vertentes são direcionadas para $\mathrm{W}$ e NW.

No médio curso, na margem esquerda do córrego ocorre um equilíbrio entre vertentes direcionadas para o NE, SE e SW e na margem direita vertentes no sentido W e NW. No alto curso da bacia, na margem esquerda do córrego, encontram-se vertentes direcionadas para o S e SE, e na margem direita vertentes inclinadas para o NE, com algumas indicações para o W, E e SE.

Dessa forma, as vertentes que recebem maior insolação diurna são as voltadas para o N, NW, W e $\mathrm{NE}$, e as que recebem menor insolação são as voltadas para SW, S, SE e E. Assim, verificou-se que as áreas que recebem maior quantidade de calor e luminosidade na extensão da bacia do córrego Tenente encontram-se no baixo e médio curso da margem direita do córrego, onde há presença de vertentes com orientação W-NW e $\mathrm{NW}-\mathrm{W}$, sendo essas as áreas propícias ao uso agrícola pois elas requerem maior intensidade de iluminação solar, assim como determinadas instalações urbanas.

USO DO SOLO DE 1970 A 2006 As primeiras ocupações nessa região ocorreram no século XVI, para assegurar e legitimar a presença espanhola, enquanto no século XVII surgiram várias aldeias jesuíticas. No final desse século os bandeirantes paulistas invadiram e destruíram esses aldeamentos denominados na época como Guairá. Desse modo, essa região ficou à margem do processo de colonização por quase um século e meio (Lima 1993). No século XX, com as concessões de terras localizadas nas regiões Norte e Noroeste do Paraná, foi retomado o processo de ocupação e o avanço da colonização na região teve como cultura inicial o café,

Tabela 3 - Distribuição areal $\left(\mathrm{km}^{2}\right)$ das classes de declividade (\%) na bacia em estudo.

\begin{tabular}{l|l}
\hline Classes $(\%)$ & Área $\left(\mathrm{km}^{2}\right)$ \\
\hline$>30$ & 0.03 \\
\hline $20-30$ & 0.23 \\
\hline $12-20$ & 5.19 \\
\hline $5-12$ & 13.9 \\
\hline$<5$ & 10.2 \\
\hline Área total da bacia & 29.54 \\
\hline
\end{tabular}

que perdurou até meados da década de 1970, quando o mesmo começou a ser substituído em decorrência da queda de preços nos mercados internacionais, falta de incentivos governamentais, culminando com as geadas de 1975, que praticamente completaram a erradicação dessa cultura da região (Fajardo \& Moro 2000).

Gradativamente, os cafezais foram sendo substituídos por outras culturas, destacando-se o trigo, o milho, o algodão, a cana-de-açúcar, associadas com atividades agropecuárias. Nos últimos anos o governo do estado, juntamente com as cooperativas e outras instituições públicas, desencadearam um novo projeto para a região Noroeste denominado "Arenito Nova Fronteira", visando o desenvolvimento agrícola e com investimentos de infraestrutura. Esse programa, em andamento, tenta evitar o êxodo rural e melhorar as condições de vida da popula- 


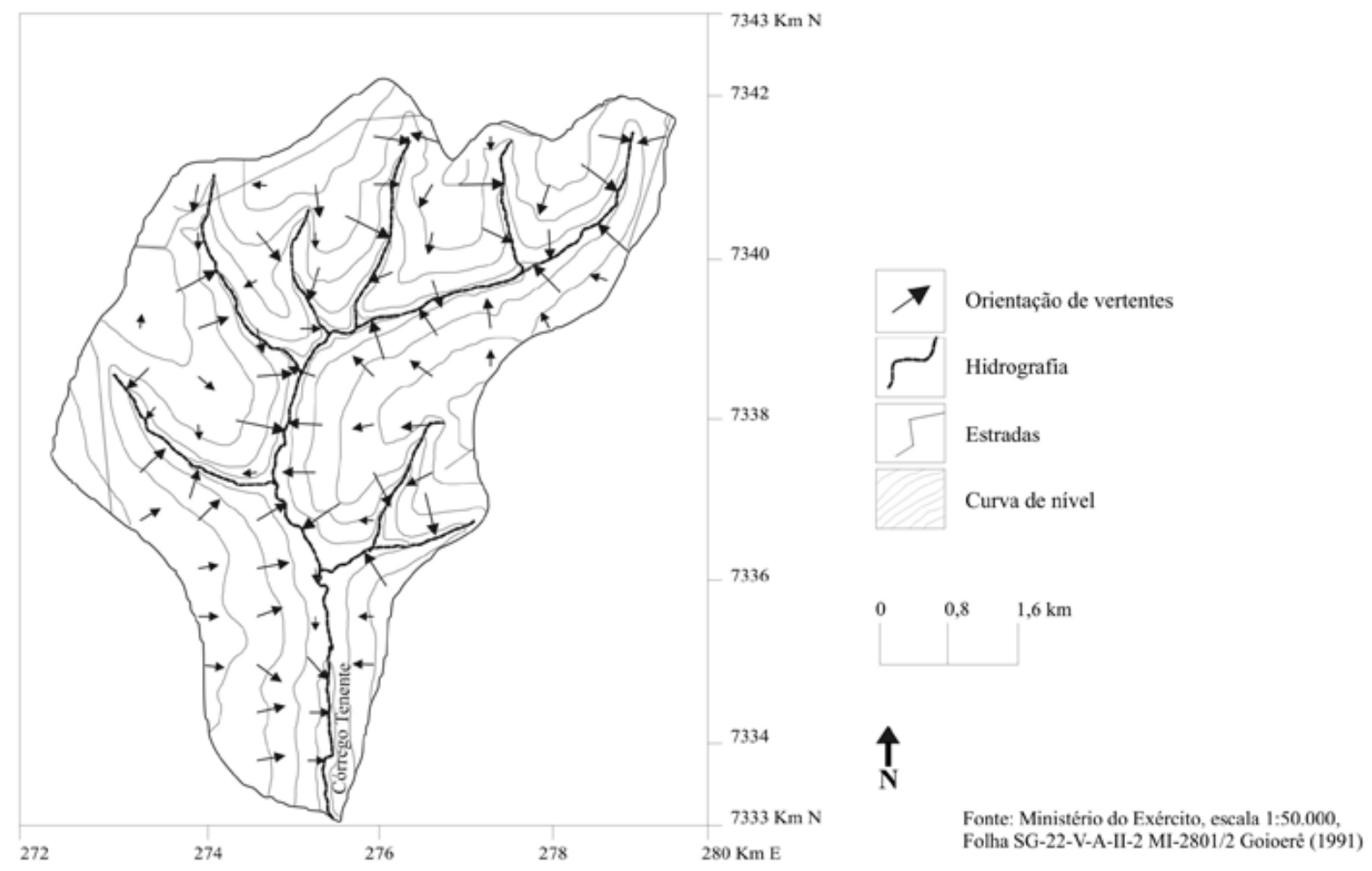

Figura 5 - Carta de orientação de vertentes da bacia do córrego Tenente/Mariluz/PR.

ção do noroeste paranaense. O programa "Arenito Nova Fronteira" visa a recuperação dos solos sobre a Formação Caiuá, com o uso de novas tecnologias para o aproveitamento de forma adequada desses materiais. Com essa perspectiva, apoio técnico e financeiro, os produtores substituíram suas culturas de subsistência e as pastagens, por vezes degradadas, pelas culturas principalmente de soja e cana-de-açúcar. No entanto, nem sempre os investidores obedecem às propostas originais do projeto.

A análise temporal, 36 anos, do uso do solo da bacia foi feita em três períodos distintos: 1970, 1980 e 2006.

O uso do solo que predominava em 1970 na bacia eram as culturas permanentes, principalmente o café e campos secundários. Nas proximidades dos principais cursos d'água havia uma concentração de resquícios florestais nativos, por vezes já alterados, aliados aos fragmentos isolados da vegetação ripária degradada e áreas antropizadas com pastagens isoladas e normalmente localizadas nos topos das vertentes (Fig. 6).

Em 1980 o uso do solo da bacia mostra a mudança gradativa da cultura cafeeira para outras culturas permanentes e temporárias, como o trigo, o milho, o algodão, a cana-de-açúcar e as pastagens. As concentrações dos resquícios florestais e da vegetação ripária degradada permaneceram em algumas áreas da bacia, as áreas antropizadas com pastagens diminuíram e surgiram áreas de campos secundários (Fig. 7).

Em 2006, o uso do solo da bacia continua em uma mudança gradativa de culturas, predominando a cultura da soja e as pastagens. As concentrações dos resquícios florestais permanecem em algumas áreas, aliadas aos fragmentos isolados da vegetação ripária degradada. No entanto, elas diminuíram se comparadas com 1970, assim como as áreas antropizadas com pastagens, mas algumas áreas de campos secundários permaneceram (Fig. 8).

MORFOPEDOLÓGICA Essa carta exibe os principais indicadores geoambientais de degradação verificados na bacia a partir dos atributos mais relevantes para esta análise, o substrato rochoso, a cobertura pedológica e a geomorfometria e o uso do solo a partir de 1970 (Fig. 9).

O substrato rochoso encontra-se aflorante principalmente no sopé das vertentes, próximo aos cursos d'água em afloramentos basais com espessuras variando de $0,5 \mathrm{~m}$ a $5 \mathrm{~m}$ em vários graus de alteração. O solo residual compõe uma cobertura pedológica com até $15 \mathrm{~m}$ de espessura, formada por solos diferenciados e classificada em Latossolos vermelhos na alta vertente. Nos setores de média vertente ocorrem os Argissolos vermelho-amarelos que transicionam, no sopé, para a associação Gleissolo pouco húmico e Neossolo Quartzarênico.

As vertentes da bacia do Córrego Tenente apresentam, em geral, na alta vertente forma retilínea, na média vertente forma convexa e na baixa vertente forma côncava e os topos aplainados. Foi identificada na área a ocorrência de vários tipos de feições erosivas ao longo das vertentes que estão condicionadas principalmente à dinâmica hídrica, que é preferencialmente vertical na alta vertente, passando a lateral a partir da média vertente até o sopé. As feições erosivas catalogadas foram as dos tipos laminar, linear (sulcos), piping e erosão marginal.

O setor mais favorável ao desenvolvimento de feições erosivas ocorre a partir da transição Argissolo 

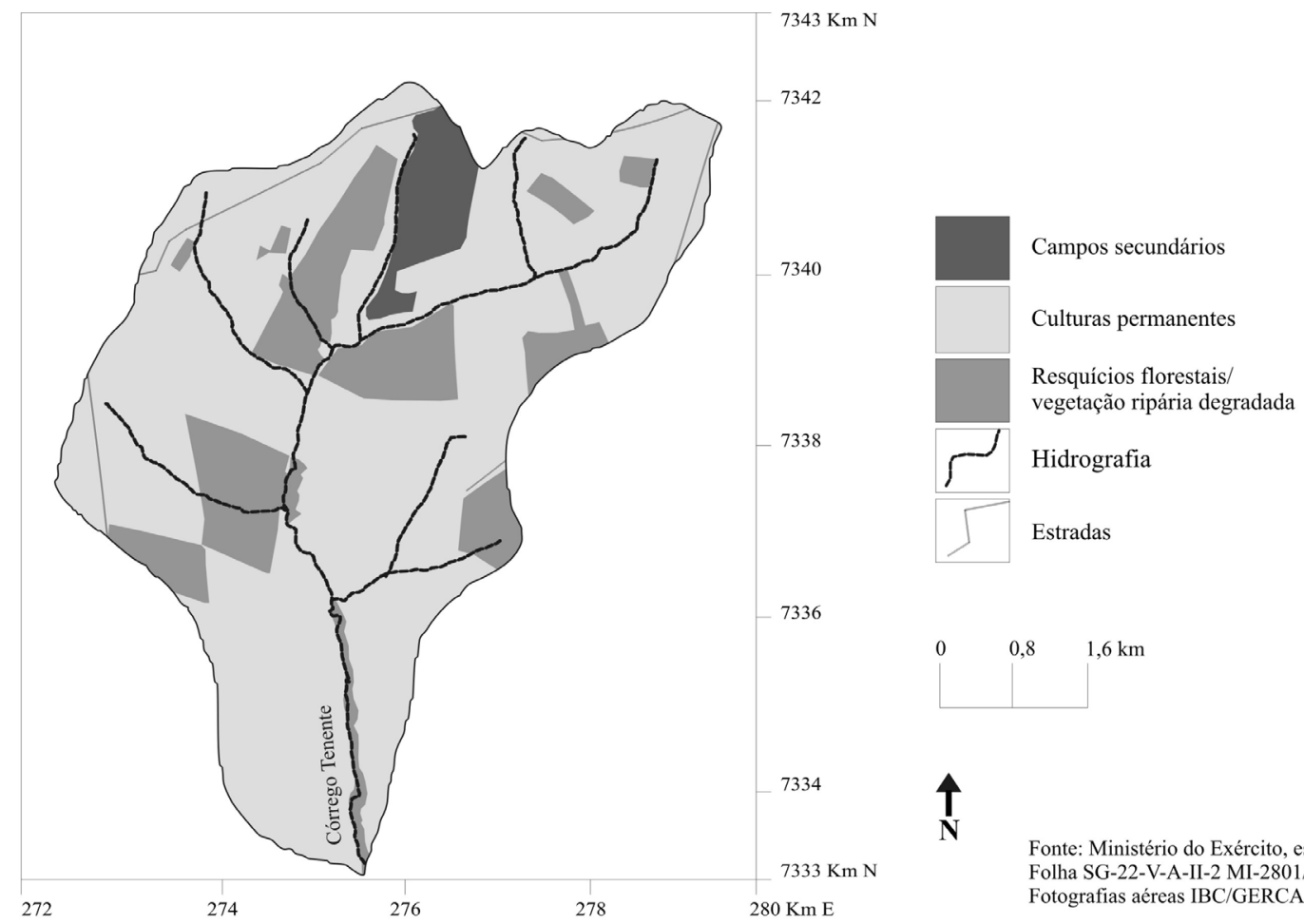

Figura 6 - Carta de uso do solo em 1970 da bacia do córrego Tenente/Mariluz/PR.

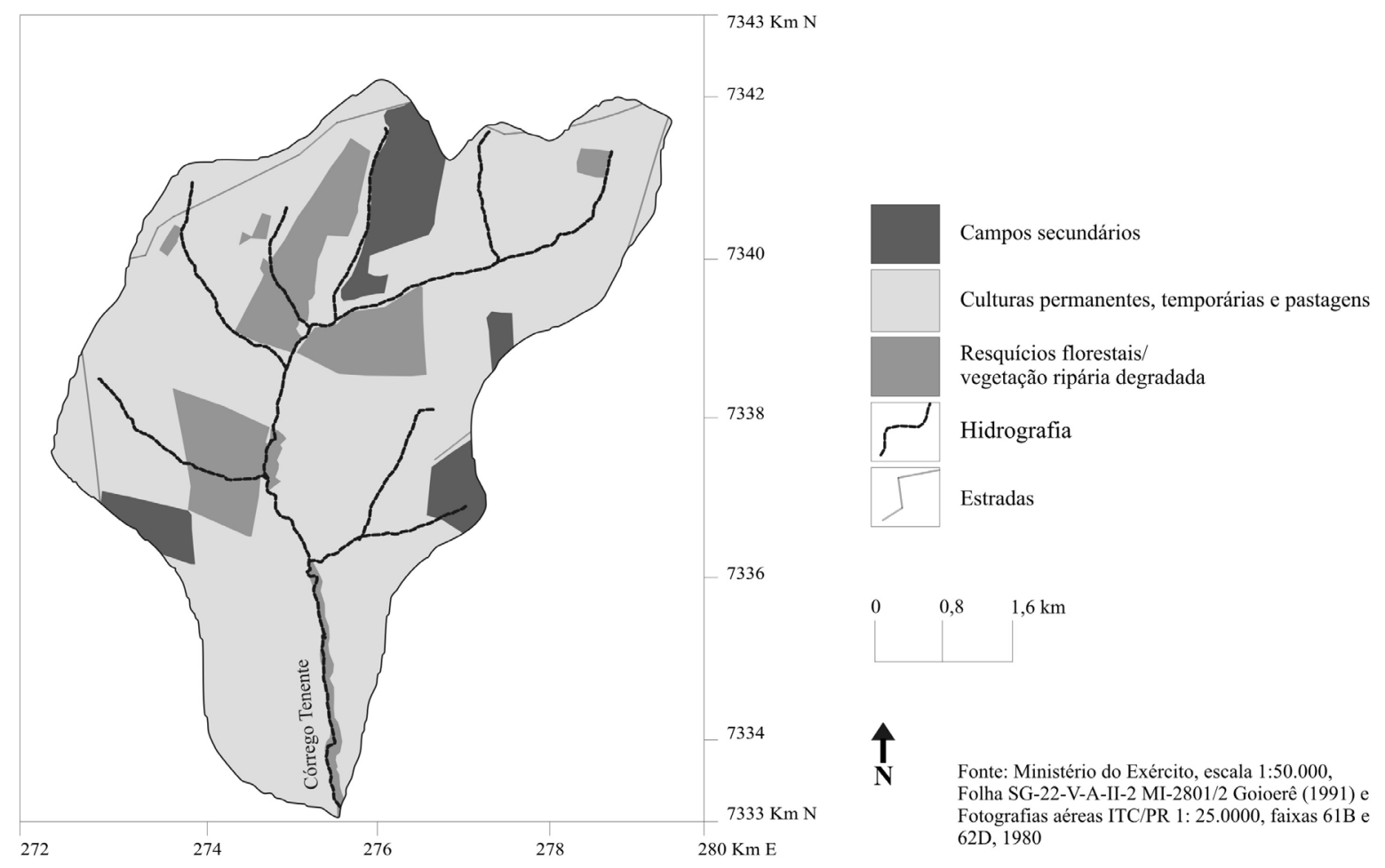

Figura 7 - Carta de uso do solo em 1980 da bacia do córrego Tenente/Mariluz/PR.

para o Neossolo Quartzarênico em direção a jusante, dade de infiltração da água, que, aliados à forma convedevido aos contrastes texturais, estruturais e à capaci- xa e à declividade da vertente, favorecem, nesse setor, 


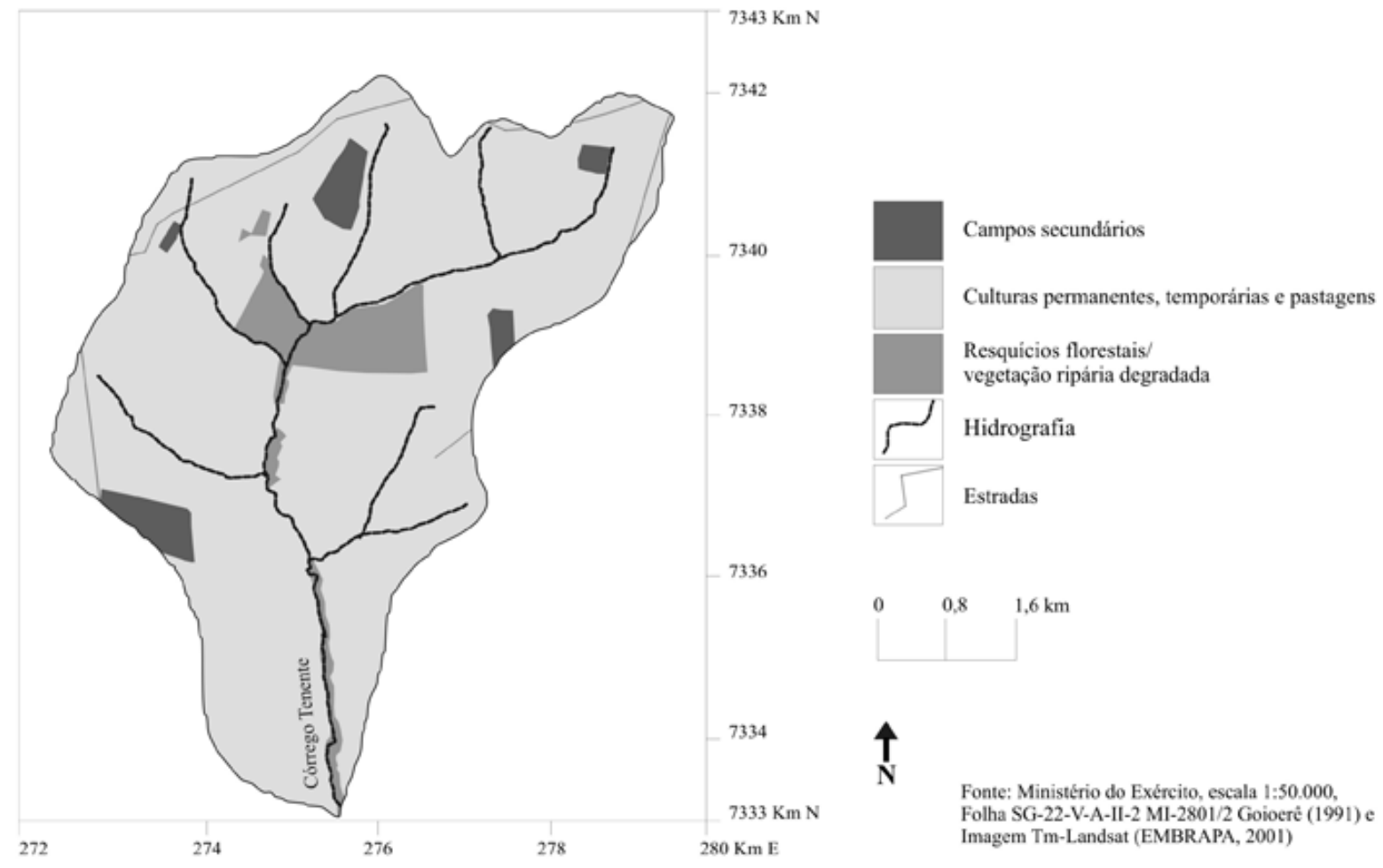

Figura 8 - Carta de uso do solo em 2006 da bacia do córrego Tenente/Mariluz/PR.

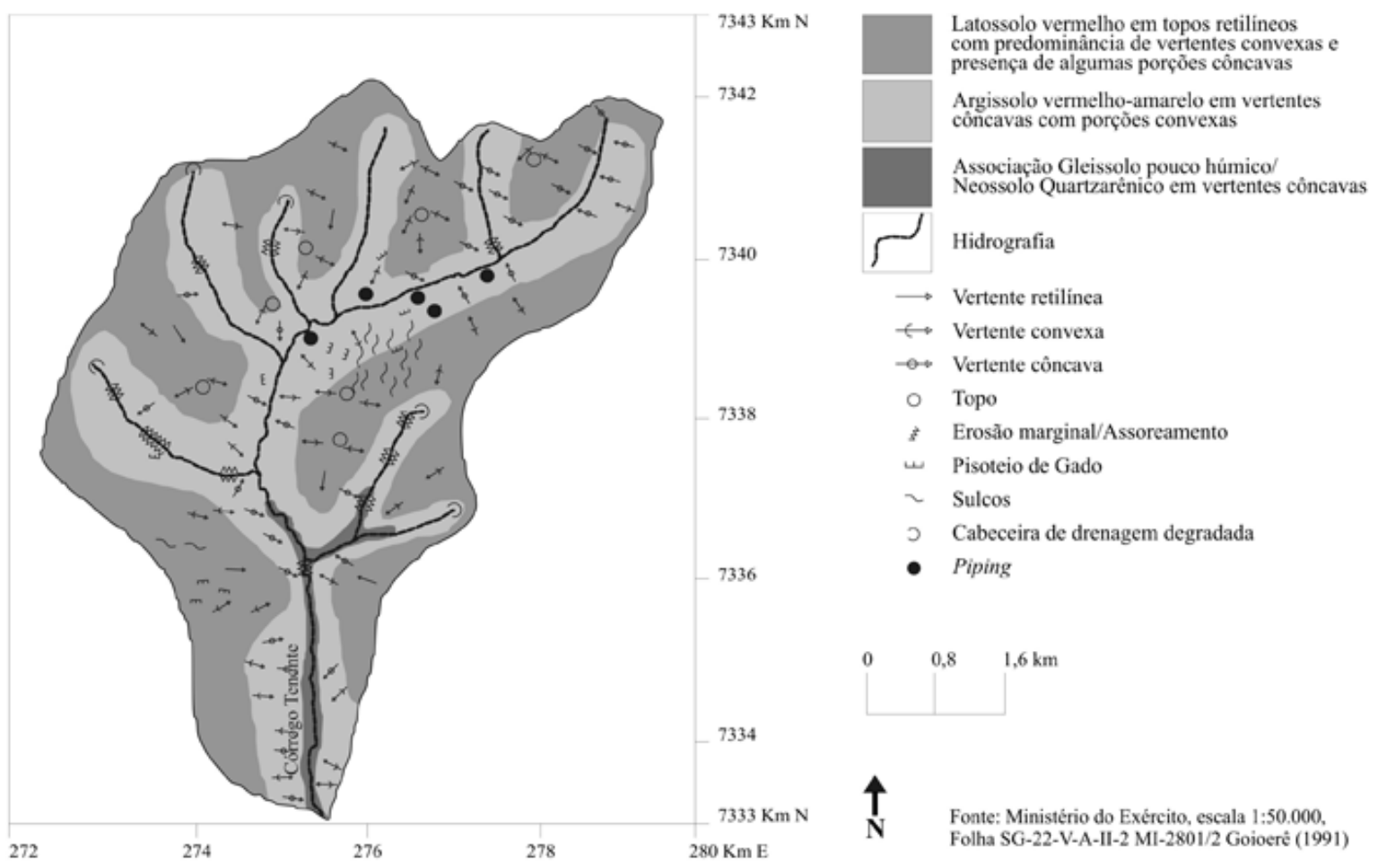

Figura 9 - Carta morfopedológica da bacia córrego do Tenente/Mariluz/PR.

o aumento dos fluxos hídricos laterais superficiais e suspensos. Portanto, a cobertura pedológica apresenta sérias limitações ao uso do solo devido à alta suceptibi- lidade da ocorrência de feições erosivas desencadeadas principalmente por agentes hídricos associados com a ausência da cobertura vegetal. 
Essas observações, feitas ao longo do levantamento, foram corroboradas por Muratori (1997). A autora destacou em sua pesquisa que as coberturas arenosas desta região entraram em desequilíbrio, principalmente após o desmatamento da floresta original, pois ocorreu uma ação anômala de energia, sob condições do clima atual, semelhante àquelas impostas no passado sob condições de clima seco. Com isso, antigas acumulações de areia em processo de evolução pedogenética passaram a sofrer ação de fenômenos erosivos. Devido as propriedades físico-químicas desses tipos de solos, estes devem ser utilizados e manejados obedecendo a rigorosas técnicas de controle e preservação, pois a não-regularidade na manutenção nesses tipos de obras de controle pode acarretar prejuízos incomensuráveis posteriormente, Souza (2001). Verificam-se várias destas situações em campo na bacia, principalmente com as rupturas de curvas de nível, que aceleram o início de feições erosivas lineares (Fig. 10).

Os usos do solo atuais, principalmente as pastagens e a cultura da soja, colaboram diretamente para a degradação geoambiental da bacia. Nas pastagens é comum o surgimento de feições erosivas tipo sulcos, favorecidos pelo pisoteio do gado. No caso da soja, naqueles períodos de pós-colheita quando os solos ficam expostos sem cobertura vegetal e aliado aos períodos de chuva favorecem ao surgimento de feições erosivas. Outro tipo de degradação geoambiental ocorre quan-

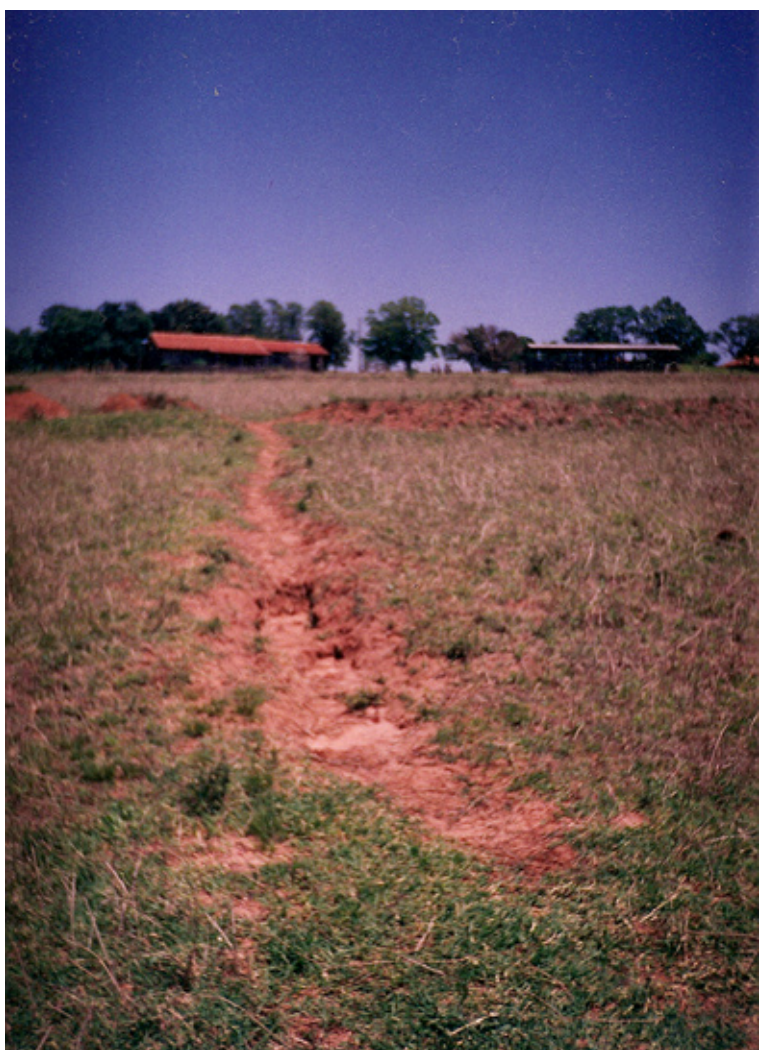

Figura 10 - Vista para área com rompimento de curvas de nivel. do as plantações de soja que são feitas normalmente até as margens dos cursos d' água na área favorecem o agravamento da degradação devido a ausência da mata ripária (Figs. 11 e 12).

Ao longo dos cursos d'água, e principalmente nas margens do córrego Tenente, ocorre a presença de feições erosivas do tipo marginal e piping (Fig. 13), com a presença de movimentos de massa, abatimentos do material arenoso no sopé das vertentes (Fig. 14).

A ocorrência dos piping ocasiona muitas vezes abatimentos dos materiais arenosos com extensões laterais de até $150 \mathrm{~m}$. Esses abatimentos concentram as águas pluvias, que podem dar início a sulcos e evoluir posteriormente a ravinas e voçorocas.

As principais cabeceiras de drenagens encontram-se degradadas e com ausência de vegetação, por vezes assoreadas pelos materiais remobilizados e carreados pelas águas pluviais durante os períodos de cultivo. Além das cabeceiras com materiais remobilizados, em geral os cursos d'água são assoreados. Esse assoreamento da bacia tende a aumentar para jusante.

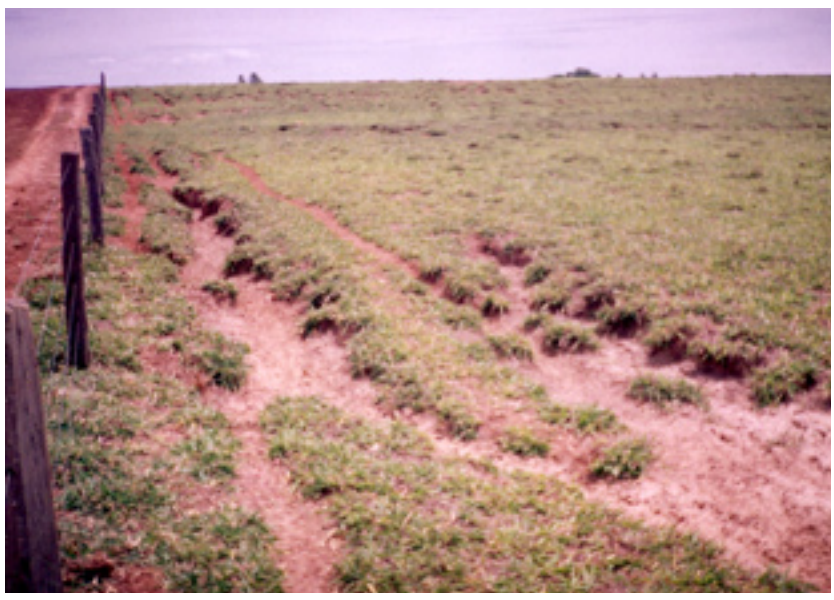

Figura 11 - Vista para área com pisoteio de gado.

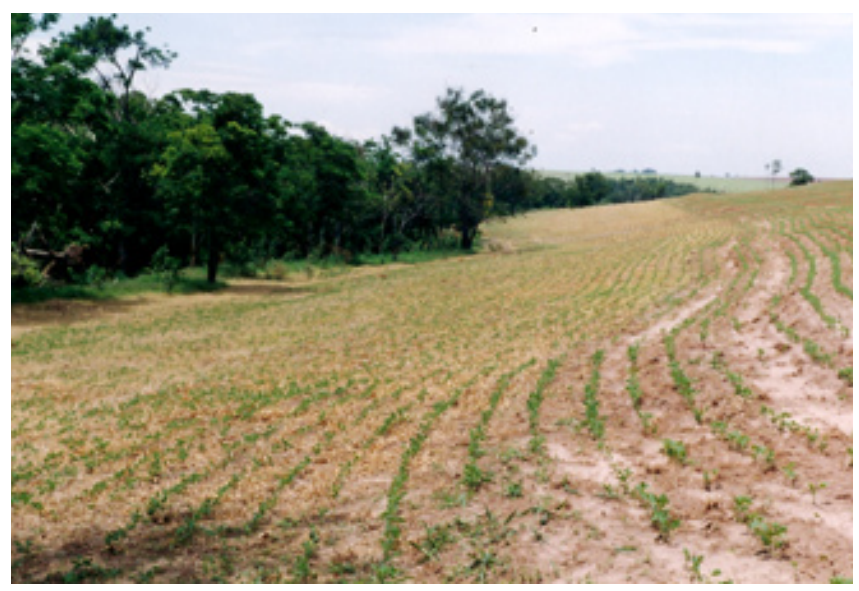

Figura 12 - Vista para área com plantação de soja até as margens dos fragmentos da mata ripária. 


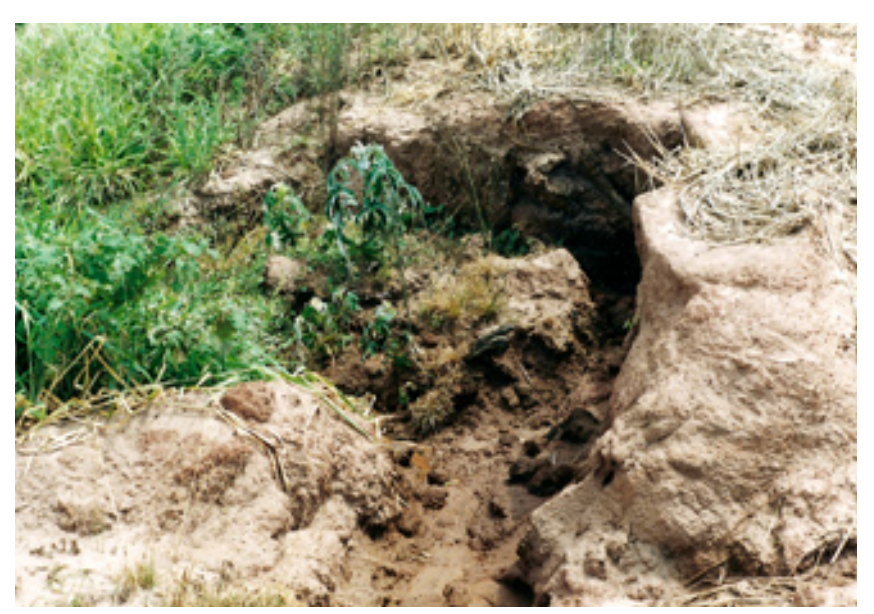

Figura 13 - Mostra um dos locais da área de estudo com a presença de piping.

CONCLUSÕES O diagnóstico geoambiental realizado na bacia do córrego Tenente enfatizou principalmente o meio físico, com o levantamento de atributos que contribuíssem para a análise da degradação da bacia.

As análises das cartas temáticas evidenciaram que os principais problemas de degradação ambiental da bacia são a ocorrência de diversas formas de feições erosivas, movimentos de massa e assoreamentos dos canais de drenagens.

Esses problemas são agravados após os períodos chuvosos, uma vez que as formas erosivas já instaladas são ampliadas e outras surgem, principalmente a partir do terço inferior das vertentes em direção ao sopé.

As perspectivas de lucros rápidos e ou a necessidade de ampliar a produção para saldar compromissos financeiros fez com que muitos produtores

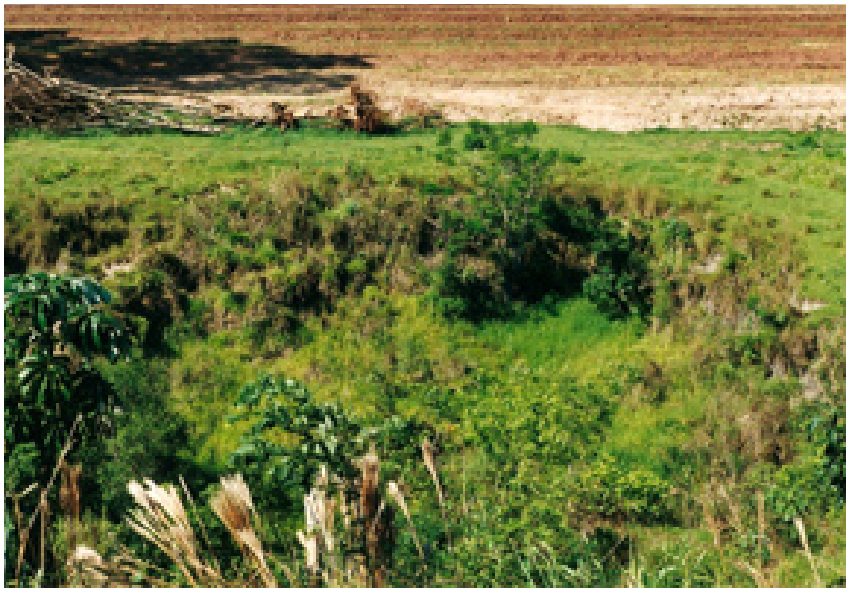

Figura 14 - Exibe abatimentos do material arenoso no sopé das vertentes.

ampliassem suas áreas de cultivo até as margens dos córregos e nascentes, conseqüentemente destruíram a vegetação ao longo dessas drenagens, como pode ser verificado ao longo dos 36 anos analisados no uso e ocupação da bacia.

Dentre as cartas temáticas elaboradas destacamse a carta de orientação de vertentes como uso preventivo de ocupação dos solos, assim como o uso da carta morfopedológica para diagnósticos geoambientais em bacias hidrográficas.

Agradecimentos Os autores agradecem o apoio logístico da Prefeitura Municipal de Mariluz, do Escritório Regional da EMATER, do Departamento de Geografia da Universidade Estadual de Maringá (DGE/UEM) e dos alunos do bacharelado do Curso de Geografia da UEM do ano letivo de 2004.

\section{Referências}

AUTODESK 2000. AutoCAD, version 2000. USA, CD.

Beltrame A.V. 1994. Diagnóstico do meio fisico de bacias hidrográficas: modelo e aplicação. EDUFSC, Florianópolis, $112 \mathrm{p}$.

Bennett H.H. 1939. Soil conservation. New York, Mc GrawHill, $993 \mathrm{p}$.

BRASIL. 2001. Estatuto da Cidade 2001. Lei no 10.257, de 10/07/2001.Disponível em: https://www.planalto.gov.br/ ccivil_03/Leis/LEIS_2001/L10257.htm. Acessado em 10/04/2008.

Campos J.O. 1985. Propriedades físicas dos Arenitos Caiuá. Rev. Bras. Geoc., 4:35-56.

Carson M.A. \& Kirkby M.J. 1975. Hillslope form and process. Cambridge University Press, USA, 475 p.

Castro J.F. \& Viadana A.G.A. 2002. A relevância da cartografia nos estudos de bacias hidrográficas: os exemplos da bacia do rio Curumbataí, Geogr., 27(3):157-169.

Chiossi N.J. 1975. Geologia aplicada à engenharia. São Paulo, EDUSP, 427 p.
Correia A.L.F. \& Fontes A.L. 2005. Caracterização morfopedológica da sub-bacia do rio Jacarecica (SE). In: SBGA, Simp. Bras. Geogr. Fís. Apl., 11, São Paulo, Anais, p. 3900-3910.

De Biasi M. 1990. A carta clinográfica: os métodos de representação e sua confecção. Rev. Dep. Geogr., 6:45-60.

De Biasi M., Semielli M.H.R., Luchesi E.S., Omaki N.E. 1977. Cartas de orientação de vertentes: confecção e utilização. Cartogr., 1:1- 4.

EMPRESA BRASILEIRA DE PESQUISA AGROPECUÁRIA (EMBRAPA). 2001. Imagens TM-Landsat. São José dos Campos.

Fajardo S. \& Moro D.A. 2000. O complexo agroindustrial e a atuação das cooperativas agrícolas no norte central do estado do Paraná. Bol. Geogr., 18(1):85-111.

Fernandes L.A. 1992. A cobertura cretácea e suprabasáltica no Paraná e pontal do Paranapanema (SP): os grupos Bauru e Caiuá. Dissertação de Mestrado, Instituto de Geociências, Universidade de São Paulo, 129 p. 
Fournier F. 1960. Climat et erosion. Press Universitaires de France, 199 p.

Gasparetto N.V.L \& Carvalho A. 2001. Origem e morfologia dos grãos de quartzo da cobertura pedológica na região noroeste do Paraná-PR. Pesq. Geoc., 28(2):197-203.

Gasparetto N.V.L. 1999. As formações superficiais do noroeste do Paraná e sua relação com o Arenito Caiuá. Tese de Doutorado, IGc, Universidade de São Paulo, 185 p.

GEOLOGICAL SOCIETY ENGINERERING GROUP WORKING PARTY REPORT. 1990. Tropical Residual Soil. The Quaterly Journal of Engineering Geology, 23(1): 4-101.

Gol' Tsberg I.A. 1969. Use for morphometric indexes in microclimatology: microclimate of URSS. Jerusalem, Translated from Russian-Israel, Program for Scientific Translations, 28-44p.

INSTITUTO AGRONÔMICO DO PARANÁ (IAPAR). 2003. Cartas Climáticas do Estado do Paraná. Escala 1: 50.000. Disponível em http://www.pr.gov.br/iapar/sma/ Cartas Climaticas. Acessado em 10/12/2006.

INSTITUTO BRASILEIRO DO CAFÉ (IBC). 1970. Foto aérea. Escala 1:25.000, São Paulo.

INSTITUTO BRASILEIRO DE GEOGRAFIA E ESTATÍSTICA (IBGE) 1991. Folha Topográfica de Goioerê. SG22-V-AS-II-2-MMI-2801/2. Goioerê, Mapa Topográfico, escala 1:50.000.

INSTITUTO PARANAENSE DE DESENVOLVIMENTO ECÔNOMICO E SOCIAL (IPARDES). 2005. Perfil municipal de Mariluz. Disponível em: http:/www. ipardes.gov.br/perfil_municipal/MontaPerfil.php/Município. Acessado em 12/12/2006.

INPE 2004. SPRING, versão 4: Geoprocessamento ao alcance de todos. São José dos Campos, BR, INPE, 1 CD.

INSTITUTO DE TERRAS E CARTOGRAFIA 1980. (ITC). Foto aérea. Escala 1:25.000, Curitiba Fx 61B - 62D.

Köppen W. 1948. Climatologia. Con un estudio de los climas de la Tierra. FCE, México.

Lima M.G. 1993. A sobrevivência dos sítios rurais em Moreira Sales - PR. Dissertação de Mestrado, Departamento de Geografia, Universidade de São Paulo, 124 p.

Maack R. 1981. Geografia física do estado do Paraná. 1 ed., Curitiba (PR), Banco de Desenvolvimento do Paraná, Universidade Federal do Paraná e Instituto de Biologia e Pesquisas Tecnológicas, $350 \mathrm{p}$.

Maranesi D.A. \& Campos J.O. 1987. Avaliação preliminar sobre a utilização de sondagens para obtenção de testemunhos e compartimentação geotécnica dos Arenitos Caiuá. In: ABGE, Congr. Bras. Geol. Eng., 5, São Paulo, Anais, p. 4101-4107.

Morgan R.P.C. 1995. Soil erosion \& Conservation. $3^{\text {th }}$, Essex, Longman Scientific \& Techinical, EUA, 298 p.

Muratori A.M. 1997. A degradação da paisagem na região noroeste do estado do Paraná: condicionantes naturais e antrópicos. In: ABEQUA, Congr. Associação Bras. Est. Quater., Reu. Quater. Am. Sul., 6, Curitiba/São Paulo, Anais, p. 213-216.

Nakashima P. 2000. Sistema Pedológico da região noroeste do estado do Paraná: distribuição e subsídios para o controle da erosão. Tese de Doutorado, Departamento de Geografia, Universidade de São Paulo, 1:162 p.

Oliveira C. 1988. Curso de cartografia moderna. Rio de Janeiro, IBGE, $152 \mathrm{p}$.

PREFEITURA DO MUNICÍPIO DE MARILUZ 2006. Imagem. Disponível em: http://www.e-prefeituras.pr.gov. br/sites/prefeitura/cmaltopiquiri/Prefeitura/mariluz.gif. Acessado em 10/10/2006.

Ribeiro J.C. \& Salomão F.X.T. 2003. Abordagem morfopedológica aplicada ao diagnóstico e prevenção de processos erosivos na bacia hidrográfica do alto rio da Casca, MT. Geoc., 22(1):83-95.

Riccomini C., Gimenez Filho A., Pires Neto A.G., Stein D.P., Almeida F.F.M., Dehira L.K., Melo M.S., Braga T.O., Ponçano W.L. 1981. Características da porção basal da Formação Caiuá, no noroeste do Paraná. In: SBG, Simp. Reg. Geol. Curitiba, 3, Atas, 2:34-48.

Ross J.L.S. 1991. Geomorfologia: ambiente e planejamento. 2 ed., São Paulo, Contexto, 84 p.

Soares P.C., Landim P.M.B., Fúlfaro V.J., Sobreiro Neto A.F. 1980. Ensaio de caracterização estratigráfica do cretáceo no estado de São Paulo, Grupo Bauru. Rev. Bras. Geoc., 10(3):177-185.

Souza M.L. 2001. Proposta de um sistema de classificação de feições erosivas voltados a estudos de procedimentos de análises de decisões quanto a medidas corretivas, mitigadoras e preventivas: aplicação no município de Umuarama (PR). Tese de Doutorado, Instituto de Geociências e Ciências Exatas, Universidade Estadual Paulista Campus de Rio Claro, 284 p.

Sugio K. 1980. Fatores paleoambientais e paleoclimáticos e subdivisão estratigráfica do Grupo Bauru. Mesa Redonda "A Formação Bauru no estado de São Paulo e regiões adjacentes”. São Paulo, SBG, Coletânea de Trabalhos e Debates, Núcleo de São Paulo, 15-30 p.

GOLDEN SOFTWARE. 1999. Surfer for Window, version 7. Colorado, USA, 1 CD-ROM.

Varnes D.J. 1978. Slope movement and typs and processes. In: Schuster R.L. \& Krizek R.J. (eds.) Landslides: Analysis and Control. Transportation Research Bord, 176:963.

Manuscrito ID 9107

Submetido em 18 de setembro 2007 Aceito em 20 de junho de 2008 Sistema eletrônico de submissão 